\title{
How plants cope with heavy metals
}

\author{
Katrin Viehweger
}

\begin{abstract}
Heavy metals are naturally occurring in the earth's crust but anthropogenic and industrial activities have led to drastic environmental pollutions in distinct areas. Plants are able to colonize such sites due to several mechanisms of heavy metal tolerance. Understanding of these pathways enables different fruitful approaches like phytoremediation and biofortification.

Therefore, this review addresses mechanisms of heavy metal tolerance and toxicity in plants possessing a sophisticated network for maintenance of metal homeostasis. Key elements of this are chelation and sequestration which result either in removal of toxic metal from sensitive sites or conduct essential metal to their specific cellular destination. This implies shared pathways which can result in toxic symptoms especially in an excess of metal. These overlaps go on with signal transduction pathways induced by heavy metals which include common elements of other signal cascades. Nevertheless, there are specific reactions some of them will be discussed with special focus on the cellular level.
\end{abstract}

Keywords: Heavy metals; Tolerance; Toxicity; Signaling; Sequestration; Chelation

\section{Review}

\section{Introduction}

Basal heavy metal tolerance is presumably found in all plant species. Thereby, they run a complex system consisting of uptake/efflux, transport/sequestration and chelation (Figure 1). These key elements are involved tightly in homeostasis of essential metal micronutrients. The more or less characteristic of these elements divide the plant kingdom into two groups: (hyper)accumulating and nonaccumulating plants.

This review will provide an overview about these tolerance mechanisms with focussing on the cellular level and signalling pathways induced by metals. The discussion of some examples will underline the multitude and complexity of signals and responses. It will trigger further work on responses towards heavy metals in plants especially in the way of low, environmentally relevant metal concentrations.

\section{Classification in non-and (hyper) accumulator plants}

The majority of plants can be classified as non-accumulator plants. Nevertheless, all have to cope with heavy metals for nutrition purposes and growing in metalliferous soils, respectively. Hence, they have to possess finely tuned

Correspondence: k.viehweger@hzdr.de

Radiotherapeutics Division, Helmholtz-Zentrum Dresden-Rossendorf eV; Institute of Radiopharmacy, P.O. Box 510119, D-01314 Dresden, Germany mechanisms for living with even toxic heavy metals (Hall 2002, Clemens 2001, 2006). The simplest strategy is to avoid metal uptake from soil or to exclude it preventing metal movement into shoots. Additionally, elements for the acquisition and sequestration of essential metals are often used. However, this can cause interferences with the plant metal homeostasis and probably induce toxic symptoms.

Such symptoms are manifold, for a review see (Fodor et al. 2002): They comprise impairments of chlorophyll synthesis resulting in chlorotic leaves, changed ratios of chlorophyll $a$ and $b$ (Murthy et al. 1984, Viehweger and Geipel 2010, Mysliwa-Kurdziel et al. 2004) and photosynthetic activity (Küpper et al. 2007), dwarfism of plants or effects on root ultrastructure (Barcelo et al. 2004) (Table 1). However, it is not clear if these impacts are either cause or consequence of metabolic perturbations in heavy metal exposed plants. Hence, it is necessary to investigate metal tolerance and toxicity on cellular and molecular level as it will be discussed in the following Sections.

A special case of metal tolerance is hypertolerance. Metalhypertolerant plants except hyperaccumulators are able to exclude metals from their tissues in order to minimize metal accumulation especially in their aboveground tissues (Baker 1981). This is the key difference to hyperaccumulating plants. Nevertheless, metal hyperaccumulation is associated

\section{实}

(c) 2014 Viehweger; licensee Springer. This is an Open Access article distributed under the terms of the Creative Commons Attribution License (http://creativecommons.org/licenses/by/4.0), which permits unrestricted use, distribution, and reproduction in any medium, provided the original work is properly credited. 


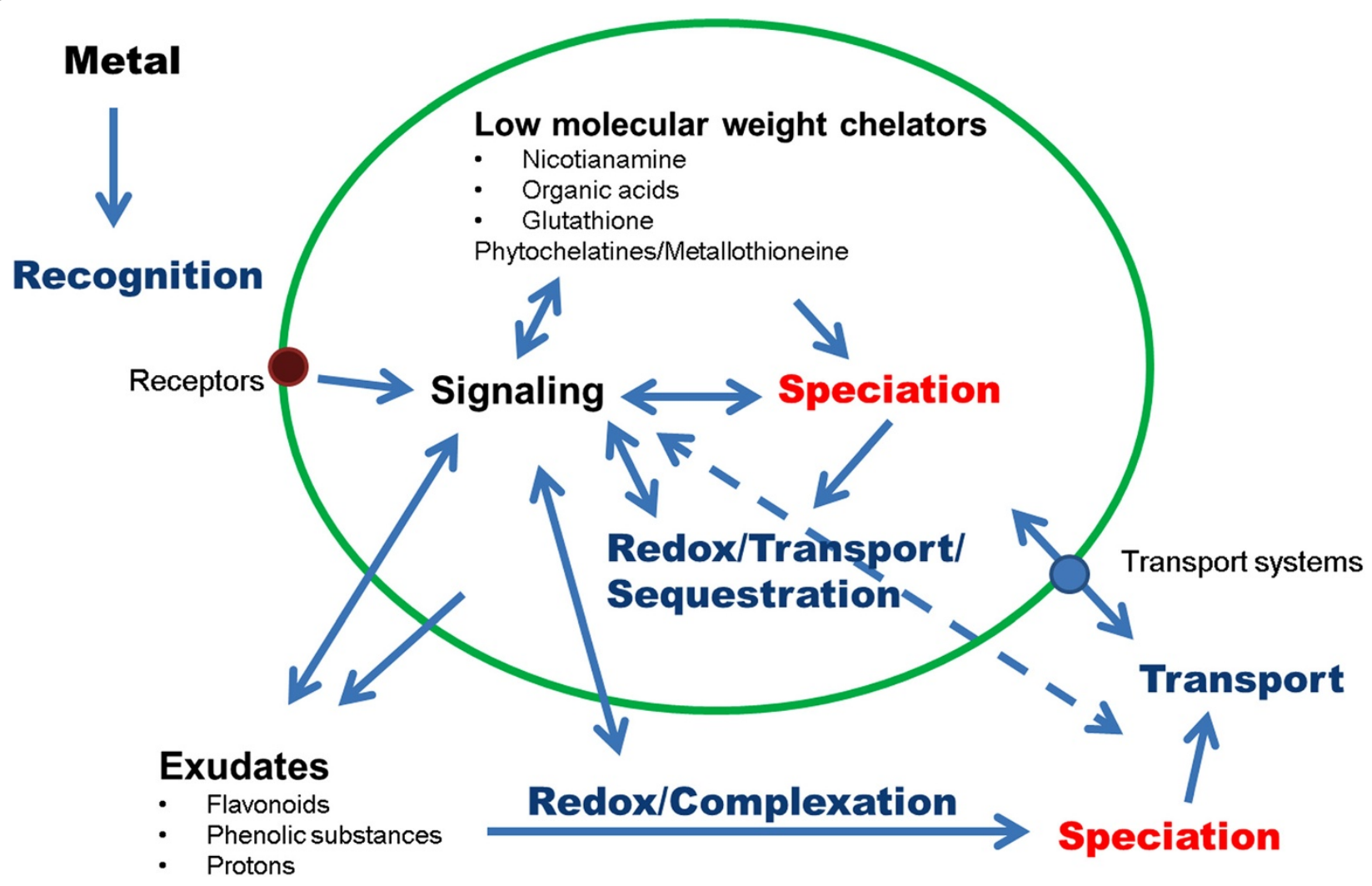

Figure 1 Short overview about some important aspects of cellular metal interaction. Arrows indicate interactions between different elements.

with metal hypertolerance revealing another strategy of detoxification.

Metal hyperaccumulating plants are characterized by a shoot/root ratio of metal accumulation $>1$ (Baker et al. 1994). Such an outstanding metal accumulation is achieved by:

(1) Overexpression of transport systems required for enhanced sequestration,

(2) Tissue-specific expression of proteins,

(3) High metal chelator concentrations.
Transcriptomic studies revealed that metal hyperaccumulation in Arabidopsis halleri has been associated with more than 30 candidate genes which are higher expressed compared with the nonaccumulator A. thaliana (Becher et al. 2004). (Pence et al. 2000) could show that the $\mathrm{Zn}^{2+}$ transporter $\mathrm{ZnT} 1$ is overexpressed in the hyperaccumulator Noccaea caerulescens compared to the non-accumulator $N$. arvense. Prominent examples are metal pumps belonging to the $\mathrm{P}_{1 \mathrm{~B}}$-adenosine triphosphatase (heavy-metal ATPases, HMA) transporter family (Axelsen and Palmgren 1998). These transporters are able to transport different metals

Table 1 Some examples of obvious toxic symptoms induced by metals

\begin{tabular}{|c|c|c|}
\hline Metal & Toxic symptoms & Reference \\
\hline $\begin{array}{l}\text { Excess or deficiency of copper, } \\
\text { excess of uranium, zinc, cadmium }\end{array}$ & $\begin{array}{l}\text { Impact on Photosynthetic apparatus: chlorotic leaves, } \\
\text { changed ratios of chlorophyll } a \text { and } b \text {, decreasing } \\
\text { net photosynthetic rate }\end{array}$ & $\begin{array}{l}\text { Ouzounidou 1995, Viehweger and Geipel 2010, } \\
\text { Monnet et al. 2001, Prasad 1995, reviewed in } \\
\text { Mysliwa-Kurdziel et al. } 2004\end{array}$ \\
\hline $\begin{array}{l}\text { Excess of aluminium, } \\
\text { cadmium, copper }\end{array}$ & $\begin{array}{l}\text { Effects on root ultrastructure: inhibition } \\
\text { of root elongation, increase in volume of } \\
\text { cortex cells, damage to epidermis }\end{array}$ & $\begin{array}{l}\text { Kidd et al. 2001, Vazquez et al. 1992, Ouzounidou, } \\
\text { 1995, reviewed in Barcelo et al. } 2004\end{array}$ \\
\hline $\begin{array}{l}\text { Excess of aluminium, } \\
\text { cadmium, lead }\end{array}$ & $\begin{array}{l}\text { Lipid peroxidation of membranes - } \\
\text { membrane leakage, change of lipid composition }\end{array}$ & $\begin{array}{l}\text { Kochian 1995, Hernandez and Cooke 1997, } \\
\text { Stefanov et al. } 1995\end{array}$ \\
\hline Cadmium, lead, uranium & $\begin{array}{l}\text { Changes in cellular concentrations of essential } \\
\text { micronutrients like iron, calcium, manganese, zinc }\end{array}$ & $\begin{array}{l}\text { Hernandez et al. 1998, Zhang et al. 2000, } \\
\text { Viehweger and Geipel } 2010\end{array}$ \\
\hline
\end{tabular}


(like $\mathrm{Zn}^{2+}, \mathrm{Cu}^{+}, \mathrm{Cu}^{2+}, \mathrm{Cd}^{2+}, \mathrm{Pb}^{2+}, \mathrm{Ni}^{2+}, \mathrm{Co}^{2+}$ ) across biological membranes. Thereby, HMA2 and HMA4 drive metal efflux out of the cell in A. thaliana (Eren and Argüello 2004) and promote xylem loading of metal in $N$. caeruslecens (Papoyan and Kochian 2004). HMA4 is responsible for zinc hyperaccumulation in A. halleri as it was shown by a RNA interference approach for downregulation of its expression. Additionally, transfer of the HMA4 gene to $A$. thaliana enables zinc partitioning into xylem vessels and up-regulated specific genes characteristic for zinc hyperaccumulators (Becher et al. 2004, Hanikenne et al. 2008). This example shows impressively the importance of regulatory gene expression and gene copy number expansions for the special trait of metal hyperaccumulation. In contrast, HMA3 is localized at the tonoplast enabling vacuolar metal influx and therefore cellular sequestration (Gravot et al. 2004). Another vacuolar membrane transporter, the $\mathrm{Zn} / \mathrm{H}^{+}$antiporter (metal tolerance protein, MTP1 a member of cation diffusion facilitator (CDF) protein family) is highly overexpressed in the aforementioned hyperaccumulating plants compared to their closed related non-accumulators (Drager et al. 2004). MTP1 is able to create a metal sink in the shoots (Gustin et al. 2009) but there are controversial discussions about its importance for hyperaccumulation.

The trait of metal chelation will be discussed in the following section.

However, the question poses: What is the selective advantage of metal hyperaccumulation? Most likely, this special trait offers a defense against pathogen and/or pathogen attack (Freeman et al. 2006, Boyd 2007). Nevertheless, fundamental questions concerning mechanisms and properties of hyperaccumulation remain elusive. This knowledge has a broad relevance in general because of accumulation of toxic metals or developments of lacks of essential micronutrients throughout the food chain (idea of biofortification) and for phytoremediation or phytomining processes.

\section{Heavy metal tolerance and toxicity on cellular level Importance of metal speciation on tolerance and toxicity Extracellular metal speciation}

Bioavailability of heavy metals in terrestrial ecosystems depends on their physico-chemical form (Blanco et al. 2004), on soil characteristics (Mortvedt 1994) and on growing plant species (Viehweger and Geipel 2010). Another important aspect is bioavailability of essential metals like iron because mechanisms facilitating the uptake of essential metals could provide a gate for non-essential even toxic substances.

A key element of acquisition of nutritional metals is the release of exudates with chelator properties from the roots into the rhizosphere. This complex formation enhances metal solubility and therefore provides a better uptake into the plant. A prominent example is the release of phenolic compounds caused by iron deficiency such as caffeic acid from Arachis hypogaea (Römheld and Marschner 1986), flavonoids from Lupinus albus (Weisskopf et al. 2006) or flavins from Beta vulgaris (Susin et al. 1993) (Cesco et al. 2010). Recent results showed evidence that flavonoids can facilitate heavy metal tolerance in A. thaliana (Keilig and Ludwig-Müller 2009). Besides iron chelation, quercetin undergoes a complexation with copper ions (El Hajji et al. 2006, Pekal et al. 2011) and uranium (Geipel et al. 2010). An example to underline this issue: Recently a close relation between iron and uranium uptake was shown in $A$. halleri, where iron starvation greatly enhanced uranium uptake (Viehweger and Geipel 2010). The stability constants of $\mathrm{U}(\mathrm{VI})$ and $\mathrm{Fe}(\mathrm{III})$ bound to Flavinemononucleotide (FMN) are relatively high (log $\mathrm{K}$ of 16 for $\mathrm{U}(\mathrm{VI})$ and $\log \mathrm{K}$ of 24 for $\mathrm{Fe}(\mathrm{III})$, mononucleotide complexes) (Geipel and Viehweger, unpublished results). Additionally to complex formations, these compounds can exhibit reductive activity towards redox-active metals changing the redox state of metals and therefore their speciation. This complex formation and reduction of non-essential heavy metals has a double edged site: On one hand, it can be used as a defense strategy producing less soluble metal complexes unsuitable for entering the plant. On the other hand, it can stabilize unstable metal redox states and competes with these processes required for acquisition of essential metals.

\section{Intracellular metal speciation}

If heavy metals enter the cytoplasm they will be bound by an appropriate cellular compound immediately. This avoids the handling of possibly toxic, free cellular metal ions and provides a coordinated involvement in metabolic pathways such as specific incorporation in metalloproteins or detoxification. Ligands for metal ions are mostly low molecular-weight compounds, a comprehensive review was provided by (Haydon and Cobbett 2007).

Well known cellular metal chelators are nicotianamine (NA) and organic acids like citrate (Curie et al. 2009, Rauser 1999). NA exhibits very high stability constants for the binding of transition metal cations (for comparison of some stability constants see (Blindauer and Schmid 2010) and is required in A. thaliana to maintain iron, zinc and copper homeostasis (Krämer 2010). As it was mentioned in a previous chapter, the concentrations of this chelator are higher in hyperaccumulators than in closely related nonaccumulators (Vacchina et al. 2003). Citrate is the predominant ligand for zinc in leaves of $N$. caerulescens (Salt et al. 1999, Küpper et al. 2000), but other organic acids such as malate are also associated with metal tolerance. (Mihalik et al. 2012) published recently that citrate facilitates uranium translocation from root to shoot interfering iron and zinc transport. This underlines the importance of organic acids for transport and sequestration of metal ions in different plant tissues and cellular compartments like the vacuole (Krämer et al. 2000, Ma et al. 2005). 
Amino acids like proline are probably involved in metal chelation (Sharma and Dietz, 2006). A key role as nickel chelator has the free amino acid histidine. Nickel increased the histidine content in the xylem of the hyperaccumulator Alyssum lesbiacum around 36-fold higher than of the nonaccumulator Alyssum montanum (Krämer et al. 1996).

A further important function of metal chelation is the possible enhancement of metal solubility.

Another low molecular-weight chelator is glutathione (reduced form GSH, oxidized form GSSG) which will be discussed in the next chapter. Functionalities of GSH (thiol and carboxylic groups) make it suitable for complex formation with heavy metals (Canovas et al. 2004, Frost et al. 2011). Complexation via the thiolate functionality is necessary for the induction of phytochelatines (PCs) (Vatamaniuk et al. 2000). Metal - PC complexes are sequestered into the vacuoles via $\mathrm{ABC}$-type transporters and therefore increase metal tolerance (MendozaCózatl et al. 2010, Song et al. 2010). Overexpression of a key enzyme in GSH biosynthesis resulted in higher steady-state levels of GSH and enhanced nickel, cobalt, zinc and to a lesser extent cadmium tolerance in $A$. thaliana (Freeman et al. 2004, Freeman and Salt 2007). This increase was proposed to result from GSH mediated reduction of oxidative stress caused by metal exposure (see next chapter).

Metallothioneins (MTs) are sulfur containing proteins inherently being highly flexible in their structure. This flexibility allows different coordination geometries for binding of different metals. Nevertheless, each MT exhibits preferences for a special metal ion due to coordination residues other than cysteine and differences in folding and stability in dependence on the bound metal (Leszczyszyn et al. 2007).

\section{Impact of heavy metals on the cellular redox environment}

Heavy metals interact with the cellular redox environment in different ways:

(1) They are able to induce the generation of reactive oxygen species (ROS),

(2) Redox-active metals can directly generate ROS via Fenton like reactions and the Haber-Weiss cycle (Stohs and Bagchis 1995, Sharma and Dietz 2009)

(3) Heavy metal detoxification consumes a major element of cellular redox homeostasis namely glutathione as direct chelator and/or as precursor of phytochelatines.

Because of the outstanding importance of the thiol tripeptide glutathione [ $\gamma$-Glu-Cys-Gly], this part of the chapter will focus on its interaction with heavy metals in afore mentioned ways.
The tightly regulated cellular glutathione homeostasis (GSH/GSSG, ratios of 100:1 are typical values) is impaired by heavy metal accumulation. This can be one reason for conflicting results regarding the GSH content upon metal exposure. Furthermore, the different points of sampling time should be attended. Copper or cadmium amendment in Arabidopsis resulted in only few changes of GSH levels in leaves during the initial 7 days (Collin et al. 2008). (Vandenhove et al. 2006) found altered levels of the glutathione pool depending on the applied uranium concentrations in Phaseolus vulgaris after a week of exposure. Concerning the initial phase of metal contact (up to 24 hours), there was no significant change of GSH whereas the amount of GSSG increased upon exposure of moderate uranium concentrations $(\leq 10 \mu \mathrm{M})$ in cell suspensions of canola (Brassica napus) (Viehweger et al. 2011. This indicates clearly its function as redox couple $\left(\mathrm{E}_{\mathrm{pH7} .4}=-264 \mathrm{mV}\right.$ at $25^{\circ} \mathrm{C}$, Schafer and Buettner 2001) and underlines the consumption of cellular reducing capacity during heavy metal accumulation and causes oxidative stress.

This reductive activity eliminates ROS generated either directly or indirectly by metals. The detoxification of ROS is GSH dependent. Such GSH consuming processes and an excess of ROS induce GSH synthesis (Foyer and Noctor 2005a, Noctor et al. 2011). Hence, plant cell are able to cope with moderate imbalances of the glutathione pool. However, higher heavy metal concentrations disrupt these elements of tolerance leading to unspecified reactions of hypersensitive response. Hence, care should be taken when extremely high, environmentally not relevant metal concentrations are applied experimentally.

Another GSH consuming process and thereby impairing the glutathione homeostasis is the synthesis of phytochelatines (PC) (Grill et al. 1985). These heavy metal chelating peptides consist of repetitive $\gamma$-glutamylcysteine units and are rapidly synthesized after metal exposure. However, not all heavy metals are capable of inducing PC synthesis such as cobalt or manganese (Grill et al. 1987). A prerequisite is the GSH - metal binding via thiolate coordination (Vatamaniuk et al. 2000). In contrast, heavy metal hyperaccumulators like $N$. caerulescens or $A$. halleri probably do not use GSH or PCs in metal hypertolerance mechanisms (Schat et al. 2002, Sun et al. 2007).

Antioxidant defense mechanisms keep the formed ROS at a low level nevertheless heavy metal stress disrupts the equilibrium between ROS generation and detoxification (Sharma and Dietz 2009). Plant cells bear a sophisticated antioxidant network based on non-enzymatic such as glutathione, ascorbate and enzymatic antioxidants like superoxide dismutase (SOD), glutathione reductase (GR) or catalase (CAT). Heavy metal accumulation caused altered capacities of such enzymes depending on plant species. For instance, Tagets erecta ( $\mathrm{Cd}$ accumulator) exhibited decreased 
levels of SOD, GR and CAT towards cadmium contact whereas Avena strigosa ( $\mathrm{Cd}$ tolerant accumulator) showed increased activities towards the same $\mathrm{Cd}$ concentrations (Uraguchi et al. 2006). These few examples illustrate that a strong antioxidant defense system is at least a beneficial trait in heavy metal tolerance (for more examples see Sharma and Dietz, 2009). However, there is no reliable basis for defining mechanistic relationships due to the lack of distinct patterns of enzyme activity. Therefore, the heavy metal, its concentration and the plant species should be carefully taken into account when investigating redox imbalances and oxidative stress induced by heavy metals.

\section{Relation between toxicity and tolerance Targets of metal toxicity}

Symptoms of metal toxicity have been studied in several plant systems and under various conditions. They can be divided in direct targets or indirect metal induced impairments of physiological pathways as it was discussed in previous sections already.

Direct targets of metals are often metalloproteins and metal binding molecules like chlorophyll (Küpper et al. 1996). Metalloproteins contain coordinated transition metals which can be substituted by chemically similar other transition metals (Table 2). A prominent example is the replacement of magnesium by nickel, cobalt or zinc in the enzyme ribulose-1,5-bisphosphate-carboxylase/oxygenase (Wildner and Henkel 1979, van Assche and Clijsters 1986) which resulted in loss of enzyme activity. Cadmium interferes with the homeostasis of the essential metals zinc and calcium (reviewed for animal cells in Moulis 2010). A surprising finding was the replacement of iron by uranium in ferritin in the microorganism Pyrococcus furiosus (Cvetkovic et al. 2010). The Irving-Williams series provides basic indication for the formation of stable complexes between cations and organic ligands (Irving and Williams 1953). A challenge in the future will be the characterisation of such metalloproteins in-vivo because of few, environmentally relevant metal concentrations which requires sensitive detection systems. Novel technologies like synchrotron X-ray fluorescence microscopy provide a powerful non-destructive technique for quanti- tative mapping of of transition metal distribution in hydrated biological samples (Fahrni 2007, Punshon et al. 2009, Donner et al. 2012). An emerging field is the investigation of the redox chemistry driven by some transition metals which can result in dramatic consequences for metabolic pathways.

Beside afore mentioned interactions between essential and non-essential heavy metals, such competitions can also occur between micronutrients (Foy et al. 1978). Known examples are interactions between iron and copper (Harris 1994) or iron and zinc (House 1999). These influences are mostly negative nevertheless there can be positive growth parameters in the case of antagonistic responses according to the classification done by Symeonidis and Karataglis (1992). A comprehensive review addressing such interactions was written by (Krupa et al. 2002).

These few examples underlines that heavy metal toxicity is partly due to the impairment of the tightly regulated homeostasis of essential metals.

\section{Mechanisms of tolerance}

As it mentioned earlier, plant cells possess a complex network for coping with heavy metals and some reactions have been touched upon in this article.

Generally speaking, the key elements of basal tolerance are sequestration and efflux (Clemens 2001). These processes resulted in the removal of toxic ions from sensitive cellular loci. Thereby transport is facilitated by metal chelators in most cases (see previous section) and requires efficient transport systems.

In addition to previously discussed cellular metal ligands, metallochaperones play an important role in facilitation of essential metals to reach the physiological destination in distinct cellular compartments without inflicting damage. A comprehensive review concerning copper metallochaperones was published by (Robinson and Winge 2010) recently. Another cellular strategy for the insertion of the correct metal cofactor into metalloproteins (metallation) is compartmentalization. Therefore distinct metals are stored at different subcellular compartments and controlled delivered to their final destinations via specific transport systems (Tottey et al. 2008).

Table 2 Some examples of metalloproteins which can be modified by metal substitution

\begin{tabular}{llll}
\hline Metal & Native metal & Protein & Reference \\
\hline $\mathrm{Cd}, \mathrm{Cu}, \mathrm{Fe}, \mathrm{Mn}, \mathrm{Pb}, \mathrm{Zn}$ & $\mathrm{Mg}$ & RuBisCo & Reviewed in Van Assche and Clijsters 1990, Siedlecka et al. 2001 \\
$\mathrm{Cd}$ & $\mathrm{Mn}$ & Oxygen evolving complex in photosystem II & Baszynski et al. 1980 \\
$\mathrm{U}, \mathrm{Al}, \mathrm{Pb}$ & $\mathrm{Fe}$ & Ferritin & Den Auwer et al. 2005, Johnston et al. 1993, Cvetkovic et al. 2010 \\
$\mathrm{Ni}$ & $\mathrm{Zn}$ & Alanyl-tRNA editing hydrolase & Cvetkovic et al. 2010 \\
$\mathrm{Zn}$ & $\mathrm{Ca}$ & Endonuclease & McCabe et al. 1992 \\
$\mathrm{Co}$ & $\mathrm{Zn}$ & ATP sulfurylase & Gavel et al. 1998 \\
$\mathrm{Pb}, \mathrm{Cd}$ & $\mathrm{Ca}$ & Calmodulin & Habermann et al. 1983, Richardt et al. 1986 \\
\hline
\end{tabular}

It should be noted that not all examples were determined in plants. 
Plant cells possess a variety of transport systems including the already mentioned heavy metal ATPases (HMAs), Nramps (natural resistance associated macrophage proteins), the cation diffusion facilitator (CDF) family, the ZIP (ZRT, IRT-like proteins) family, ABC transporters (ATP-binding cassette), cation antiporters and other putative transition metal transporters. A more detailed overview is provided by reviews written by Guerinot (2000), Hall and Williams (2003), Krämer et al. (2007) or (Puig and Penarrubia 2009) and references therein. Although they play a crucial role in maintenance the homeostasis of essential metal micronutrients they are involved in detoxification of non-essential or excess metal. Their overexpression and higher cellular density as special trait in metal hyperaccumulators was discussed in a previous chapter. Various transport systems can act as a gate for various metals because of chemical similarities of metal ions or their complexes. A prominent example for this is the iron-regulated transporter (IRT1) at the plasma membrane of roots of $A$. thaliana which exhibits a broad substrate range (Korshunova et al. 1999).

As it was mentioned before, metal sequestration in distinct cellular compartments plays a pivotal role in metal tolerance and supplement with essential metals. For this purpose cells provide a coordinated set of transport systems in each cellular membrane. An important metal sink in metal tolerant plants is the vacuole. A prominent example is the transport of metal-phytochelatin complexes into the vacuole by an unknown $\mathrm{ABC}$ transporter or by cation/proton exchanger (CAX) (Schneider et al. 2009). However, recent studies suggested that the phytochelatin-cadmium complex formation plays a more important role in detoxification than vacuole sequestration (Wojas et al. 2010).

\section{Signals generated by heavy metal exposure}

As it was discussed in previous sections, heavy metals interact with metabolic pathways and therefore are able to generate signals. Thereby, the similarity of chemical properties of different metals plays a pivotal role especially between essential and non-essential metals. However, such interaction does not inevitably have a negative impact for the plant at all points. For instance, Arabidopsis or carrot plants exhibited an obvious better root elongation when growing with uranium amendment (Straczek et al. 2009, Misson et al. 2009, Viehweger and Geipel 2010) probably due to the excretion of phenolic compounds into the rhizosphere which can stimulate root elongation (Wang 1991). This example shows as well the importance of investigations concerning whole networks of metal metabolism. Recent experiments suggested a facilitated iron acquisition in A. halleri growing on a former uranium mining dump which provided very low soluble iron minerals (Viehweger and Geipel 2010, unpublished results). Table 3 provides an insight in the complex signaling network induced by various environmental stress conditions.

\section{Signal perception}

Generally, a signal transduction pathway starts with the signal perception in the case of heavy metals with its recognition by the cell. Up to date, much less knowledge is available about a primary recognition for instance by a receptor. It is likely that the metal is mainly perceived by plasma membrane proteins responsible for metal acquisition like reductases and transporters. However, other sensors can be expected resulting from physical alterations in cellular structures induced by metal exposure. If the metal is recognised by cells the further cellular signal transduction will use elements of common signalling pathways like calcium fluxes.

\section{Cellular secondary signal molecules}

The most prominent secondary messenger is calcium (reviewed e.g. in Xiong and Zhu 2002). Treatments of the brown algae Fucus serratus with different copper concentrations inhibited or induced cytoplasmic calcium fluxes (Nielsen et al. 2003). These alternate fluxes might initiate calcium dependent protein kinases and therefore couple this universal inorganic signal to specific protein phosphorylation cascades like MAP kinase activities (Yeh et al. 2007).

Another inorganic signal is the proton which also enables fast concentration shifts (but not so fast like calcium). Proton fluxes can establish so-called "pH-signatures" in the cytoplasm (Roos et al. 1998) and thus creating specific micro-areas with for example enhanced metal solubility. Iron deficiency causes a proton efflux driven by a P-type proton ATPase (AHA7) acidifying the rhizosphere (Santi and Schmidt 2009) which induces a pH-shift in the near neutral cytoplasm. However, nothing is known about a possible impact on cellular signaling.

As it was mentioned in chapter 3.2 heavy metals are able to elicit the production of ROS. Beside their activity as aggressively reacting oxidants towards cellular macromolecules they can act as signal transduction molecules which will be discussed in Section Redox signaling induced by heavy metals.

\section{Stress signal transduction by plant hormones}

During heavy metal exposure, plants produce increased amounts of hormones such as abscisic acid or ethylene (Zengin 2006, Maksymiec 2011). Additionally, the involvement of jasmonic acid in the early response to cadmium contact in Phaseolus coccineus was described recently by Maksymiec (2011). Hence, it seems to be obviously, that elements of octadecanoid pathway interacts in metal induced signalling and even act in potential defence reactions. This pathway is part of the oxidative/redox system of plants 
Table 3 Overview of some heavy metal triggered signals in comparison to other environmental stresses

\begin{tabular}{|c|c|c|c|c|}
\hline Heavy metal & Signal & Other stress conditions & Cellular responses & References \\
\hline Copper & Calcium fluxes & Cold, drought, salinity & Phosphoprotein cascades, $2^{\text {nd }}$ signalling molecules & $\begin{array}{l}\text { Nielson et al. Nielsen et al. 2003, reviewed } \\
\text { by Sanders et al. 1999, Knight } 2000\end{array}$ \\
\hline Cadmium, chromium & $\begin{array}{l}\text { Mitogen activated protein } \\
\text { kinase (MAPK) pathways }\end{array}$ & Osmotic stress, pathogen contact & $\begin{array}{l}\text { Activation of transcription factors } \\
\text { and stress-responsive genes }\end{array}$ & $\begin{array}{l}\text { Liu et al. 2010, Ding et al. 2009, } \\
\text { reviewed in Xiong et al. } 2002\end{array}$ \\
\hline Iron & pH shifts & Pathogen contact & Induction of secondary metabolism & $\begin{array}{l}\text { Marschner and Römheld 1983, } \\
\text { Viehweger et al. } 2006\end{array}$ \\
\hline Cobalt, zinc & $\begin{array}{l}\text { Plant hormones like } \\
\text { abscisic acid or ethylene }\end{array}$ & Cold, drought, salinity & $\begin{array}{l}\text { Calcium signalling, guard cell } \\
\text { regulation (water balance) }\end{array}$ & Zengin 2006, reviewed in Zhu 2002 \\
\hline Cadmium, copper & Jasmonic acid & Pathogen contact, sugar, drought, salinity & $\begin{array}{l}\text { Defence/stress response, development, } \\
\text { induction of secondary metabolism }\end{array}$ & $\begin{array}{l}\text { Agrawal et al. 2003, Chen et al. 2006, } \\
\text { Maksymiec 2011, reviewed in Howe and } \\
\text { Schilmiller 2002, Turner et al. } 2002\end{array}$ \\
\hline $\begin{array}{l}\text { Redox-active metals like iron, } \\
\text { copper; almost all heavy metals } \\
\text { at higher concentrations }\end{array}$ & Reactive oxygen species & $\begin{array}{l}\text { Pathogen contact, cold, drought, } \\
\text { salinity, high light intensity }\end{array}$ & $\begin{array}{l}\text { Phosphoprotein cascades, activation of } \\
\text { transcription factors and stress-responsive } \\
\text { genes, activation of antioxidative defence }\end{array}$ & $\begin{array}{l}\text { Reviewed in Foyer and Noctor } \\
\text { 2005a, Ahmad et al. } 2008\end{array}$ \\
\hline
\end{tabular}


which was discussed in a previous section already. It underlines the tight regulation of metal homeostasis in a widespread network consisting of various elements.

\section{Signaling by transcription factors}

A well investigated example is the function of transcription factors (TFs) during iron starvation in plants. A detailed review concerning this was published recently (Hindt and Guerinot 2012). Early results obtained by Brown and Chaney (1971) and Brown and Ambler (1974) suggested a pivotal role of a basic helix-loop-helix (bHLH) transcription factor (named FER) in iron deficiency responses using an iron inefficient tomato mutant (Lycopersicon esculentum). FER encodes bHLH which controls the expression of genes with key functions in iron acquisition such as the iron-regulated transporter (IRT) and the ferric oxidase reductase (FRO) orthologs in tomato (Ling et al. 2002). The Arabidopsis FER ortho$\log$ is FER-like iron deficiency-induced transcription factor (FIT) (Colangelo and Guerinot 2004, Jakoby et al. 2004, Yuan et al. 2005). FIT form heterodimers with two other bHLH proteins (Yuan et al. 2008) and is iron responsive. Interestingly, two TFs of the bHLH family in Arabidopsis are involved in the iron deficiency induced synthesis and excretion of riboflavin when heterologous expressed in tobacco and sunflower (Vorwieger et al. 2007). This example underlines that TFs are essential components in the regulatory pathway connecting perception of iron deficiency and cellular reactions. Recent results provided evidence for another set of transcription factors called POPEYE network (Long et al. 2010). POPEYE (PYE) is a recently identified bHLH transcription factor, the other player is the putative E3-ubiquitin ligase called BRUTUS (BRS). Both are induced by iron deficiency in roots. The importance of this network was revealed using the pye-1 mutant which suffered from chlorosis and poor root growth under iron starvation.

Nevertheless, TFs are although induced by other heavy metals. These TFs can be involved in other cellular processes and therefore may interfere with them. For instance, ethylene-responsive element-binding factor (ERF) gene expression was detected $A$. thaliana and $A$. halleri after cadmium treatment (Weber et al. 2006). Dehydrationresponsive element-binding protein (DREB) TFs can be either up- or down-regulated by heavy metals like cadmium and copper (Ogawa et al. 2009; Ban et al. 2011). Genes encoding TFs belonging to bZIP, Myb, and zinc-finger protein families are up-regulated by cadmium exposure found by (Fusco et al. 2005), recently. The regulation of TFs plays an important role in maintaining metal-hyperaccumulating abilities. (van de Mortel et al. 2006) revealed that 131 TFs showed a more than 5-fold higher expression in T. caerulescens compared to $A$. thaliana under zinc sufficient conditions. As the terms of the discussed TFs suggested they were discovered as cellular responses after various stresses. This strengthens the idea of common response mechanisms different against biotic and abiotic threats.

\section{Redox signaling induced by heavy metals}

As it was discussed in a previous chapter heavy metal exposure can cause imbalances in the cellular redox homeostasis either by being itself redox-active or by replacing other metal ions (sometimes even redox-active ions) in biomolecules. A recently discussed issue in animal cells is the zinc coordination with sulphur donors of cysteine resulting in a redox switch with reversible oxidoreduction of the sulfur donor linked to zinc association and dissociation (Maret 2012). This phenomenon might be adopted in plant cells too and bridges the gap between coordination chemistry of metal ions in biomolecules and their resultant function.

A fundamental role in signaling is fulfilled by the generated reactive oxygen species (ROS) which can activate mitogen-activated protein kinase (MAPK) cascades in a plant species and metal dependent manner (Gupta and Luan 2003, Rentel et al. 2004). As an example, (Liu et al. 2010) demonstrated an activation of MPK3 and MPK6 via accumulation of ROS in Arabidopsis. These cascades end up by phosphorylation of transcription factors (see Cellular secondary signal molecules) interacting with gene promoters and thus inducing gene expressions. It should be noted that there are differences between metal-sensitive and metal-tolerant plants: ROS-MAPK signals cause several cellular damages like interruption of hormonal signalling, programmed cell death in metal-sensitive plants. In contrast, metal-tolerant plants are able to accumulate repair proteins such as chitinases and heat shock proteins (HSP). A more detailed overview provides a recently published review by Lin and Aarts (2012). However, it should keep in mind that ROS is produced as a response to myriad kinds of stresses and therefore could interfere with other cellular reactions. Generation of ROS after heavy metal contact is mostly an unspecific reaction due to abnormal high metal concentrations. It is a common phenomenon that excessive biotic or abiotic threats elicit nondirectional responses.

Other important elements are the soluble redox couples like glutathione or $\mathrm{NAD}(\mathrm{H}), \mathrm{NADP}(\mathrm{H})$ which provide a buffering system in the cytoplasm (Noctor 2006). Local perturbation of this system is likely a step in signal transduction processes inducing e.g. enzyme or hormone activity. These processes occur in all cellular compartments reflecting their physiological importance. Comprehensive reviews concerning this sophisticated network can be found in Foyer and Noctor (2005a,b), Grene (2002) and (Ahmad et al. 2008).

\section{Conclusion and further perspective}

Almost all plants exhibit a basal metal tolerance when facing heavy metals. Some species are even capable of 
hyperaccumulation running different tolerance reactions compared with nonaccumulating plants. However, general tolerance mechanisms are based on exclusion, chelation and sequestration processes (Figure 1).

Attention should be paid on signal transduction pathways induced by metals because they use common signal elements which can be also elicited by other environmental stresses. The critical evaluation of triggered signals and their responses is mandatory for understanding metal homeostasis. The challenge in the future will be the investigation of multiple stress factors as it occurs under real environmental conditions.

Special focus should put on low, environmentally relevant heavy metal concentrations. Therefore, the further development of sensitive detection methods and the combination of different approaches are necessary. These tools enable for instance new insights in the metalloproteome and its interactions ("metallomics"). Further knowledge about metal tolerance in plants is mandatory for several purposes:

(1) Predictions about health risk which is caused by metal accumulation in crop plants failing visible symptoms of phytotoxicity.

(2) Generation of genetically engineered plants having an enhanced accumulation of metals valuable for nutritional purposes (biofortification).

(3) Clean up of metal contaminated soils (phytoremediation) and mining of rare metals which are accumulated in plant tissues (phytomining).

\section{Competing interests}

The authors declare that they have no competing interests.

\section{Acknowledgements}

I am grateful to Dr. Gerhard Geipel (Institute of Resource Ecology) for helpful discussions and the Helmholtz-Zentrum Dresden-Rossendorf for excellent research conditions.

Received: 20 December 2012 Accepted: 13 November 2013

Published: 20 March 2014

\section{References}

Agrawal GK, Jwa NS, Shibato J, Han O, Iwahashi H, Rakwal R (2003) Diverse environmental cues transiently regulate OsOPR1 of the "octadecanoid pathway" revealing its importance in rice defense/stress and development. Biochem Biophys Res Commun 310:1073-1082

Ahmad P, Sarwat M, Sharma S (2008) Reactive oxygen species, antioxidants and signaling in plants. J Plant Biol 51:167-173

Axelsen KB, Palmgren MG (1998) Evolution of substrate specificities in the P-type ATPase superfamily. J Mol Evol 46:84-101

Baker AJM (1981) Accumulators and excluders - Strategies in the response of plants to heavy -metals. J Plant Nutr 3(1-4):643-654

Baker AJM, McGrath SP, Sidoli CMD, Reeves RD (1994) The possibility of in situ heavy metal decontamination of polluted soils using crops of metal-accumulating plants. Res Cons Rec 11:41-49

Ban QY, Liu GF, Wang YC (2011) A DREB gene from Limonium bicolor mediates molecular and physiological responses to copper stress in transgenic tobacco. J Plant Physiol 168:449-458

Barcelo J, Poschenrieder C, Prasad MNV (2004) Structural and ultrastructural changes in heavy metal exposed plants. In: Heavy metal stress in plants. Springer, Berlin, Heidelberg, p 223
Baszynski T, Wajda L, Krol M, Wolinska D, Krupa Z, Tukendorf A (1980) Photosynthetic activities of cadmium-treated tomato plants. Physiol Plant 48:365-370

Becher M, Talke IN, Krall L, Krämer U (2004) Cross-species microarray transcript profiling reveals high constitutive expression of metal homeostasis genes in shoots of the zinc hyperaccumulator Arabidopsis halleri. Plant J 37:251-268

Blanco P, Tomé FV, Lozano JC (2004) Sequential extraction for radionuclide fractionation in soil samples: a comparative study. App Rad Iso 61:345-350

Blindauer CA, Schmid R (2010) Cytosolic metal handling in plants: determinants for zinc specificity in metal transporters and metallothioneins. Metallomics 2:510-529

Boyd RS (2007) The defense hypothesis of elemental hyperaccumulation: status, challenges and new directions. Plant Soil 293:153-176

Brown JC, Ambler JE (1974) Iron-stress response in tomato (Lycopersicon esculentum). 1. Sites of Fe reduction, absorption and transport. Physiol Plant 31:221-224

Brown JC, Chaney RL (1971) Effect of iron on the transport of citrate into the xylem of soybeans and tomatoes. Plant Physiol 47:836-840

Canovas D, Vooijs R, Schat H, de Lorenzo V (2004) The role of thiol species in the hypertolerance of Aspergillus sp P37 to arsenic. J Biol Chem 279:51234-51240

Cesco S, Neumann G, Tomasi N, Pinton R, Weisskopf L (2010) Release of plantborne flavonoids into the rhizosphere and their role in plant nutrition. Plant Soil 329:1-25

Chen $\mathrm{H}$, Jones AD, Howe GA (2006) Constitutive activation of the jasmonate signaling pathway enhances the production of secondary metabolites in tomato. FEBS Lett 580:2540-2546

Clemens S (2001) Molecular mechanisms of plant metal tolerance and homeostasis. Planta 212:475-486

Clemens S (2006) Toxic metal accumulation, responses to exposure and mechanisms of tolerance in plants. Biochimie 88:1707-1719

Colangelo EP, Guerinot ML (2004) The essential basic helix-loop-helix protein FIT1 is required for the iron deficiency response. Plant Cell 16:3400-3412

Collin VC, Eymery F, Genty B, Rey P, Havaux M (2008) Vitamin E is essential for the tolerance of Arabidopsis thaliana to metal-induced oxidative stress. Plant Cell Environ 31:244-257

Curie C, Cassin G, Couch D, Divol F, Higuchi K, Jean M, Misson J, Schikora A, Czernic P, Mari S (2009) Metal movement within the plant: contribution of nicotianamine and yellow stripe 1-like transporters. Ann Bot 103:1-11

Cvetkovic A, Menon AL, Thorgersen MP, Scott JW, Poole FL, Jenney FE, Lancaster WA, Praissman JL, Shanmukh S, Vaccaro BJ, Trauger SA, Kalisiak E, Apon JV, Siuzdak G, Yannone SM, Tainer JA, Adams MWW (2010) Microbial metalloproteomes are largely uncharacterized. Nature 466:779-U718

Den Auwer C, Llorens I, Moisy P, Vidaud C, Goudard F, Barbot C, Solari PL, Funke $\mathrm{H}$ (2005) Actinide uptake by transferrin and ferritin metalloproteins. Radiochim Acta 93:699-703

Ding HD, Tan MP, Zhang C, Zhang ZW, Zhang AY, Kang YJ (2009) Hexavalent chromium $(\mathrm{VI})$ stress induces mitogen-activated protein kinase activation mediated by distinct signal molecules in roots of Zea mays L. Environ Exp Bot 67:328-334

Donner E, Punshon T, Guerinot ML, Lombi E (2012) Functional characterisation of metal(loid) processes in planta through the integration of synchrotron techniques and plant molecular biology. Anal Bioanal Chem 402:3287-3298

Drager DB, Desbrosses-Fonrouge AG, Krach C, Chardonnens AN, Meyer RC, Saumitou-Laprade P, Kramer U (2004) Two genes encoding Arabidopsis halleri MTP1 metal transport proteins co-segregate with zinc tolerance and account for high MTP1 transcript levels. Plant J 39:425-439

El Hajji H, Nkhili E, Tomao V, Dangles O (2006) Interactions of quercetin with iron and copper ions: complexation and autoxidation. Free Radic Res 40:303-320

Eren E, Arguello JM (2004) Arabidopsis HMA2, a divalent heavy metal-transporting PIB-type ATPase, is involved in cytoplasmic $\mathrm{Zn}^{2+}$ homeostasis. Plant Physiol 136:3712-3723

Fahrni CJ (2007) Biological applications of X-ray fluorescence microscopy: exploring the subcellular topography and speciation of transition metals. Curr Opin Chem Biol 11:121-127

Fodor F, Prasad MNV, Strzalka K (2002) Physiological responses of vascular plants to heavy metals. In: Physiology and biochemistry of metal toxicity and tolerance in plants. Kluwer Academic Publishers, Dordrecht, Boston, London, p 149

Foy CD, Chaney RL, White MC (1978) Physiology of metal toxicity in plants. Annu Rev Plant Physiol Plant Mol Biol 29:511-566

Foyer CH, Noctor G (2005a) Oxidant and antioxidant signalling in plants: a reevaluation of the concept of oxidative stress in a physiological context. Plant Cell Environ 28:1056-1071 
Foyer $\mathrm{CH}$, Noctor G (2005b) Redox homeostasis and antioxidant signaling: A metabolic interface between stress perception and physiological responses. Plant Cell 17:1866-1875

Freeman JL, Salt DE (2007) The metal tolerance profile of Thlaspi goesingense is mimicked in Arabidopsis thaliana heterologously expressing serine acetyltransferase. BMC Plant Biol 7:10

Freeman JL, Persans MW, Nieman K, Albrecht C, Peer W, Pickering IJ, Salt DE (2004) Increased glutathione biosynthesis plays a role in nickel tolerance in Thlaspi nickel hyperaccumulators. Plant Cell 16:2176-2191

Freeman JL, Quinn CF, Marcus MA, Fakra S, Pilon-Smits EAH (2006) Seleniumtolerant diamondback moth disarms hyperaccumulator plant defense. Curr Biol 16:2181-2192

Frost L, Geipel G, Viehweger K, Bernhard G (2011) Interaction of uranium(VI) towards glutathione - an example to study different functional groups in one molecule. Proc Radiochim Acta 1:357-362

Fusco N, Micheletto L, Dal Corso G, Borgato L, Furini A (2005) Identification of cadmium-regulated genes by CDNA-AFLP in the heavy metal accumulator Brassica juncea L. J Exp Bot 56(421):3017-3027

Gavel OY, Bursakov SA, Calvete JJ, George GN, Moura JJG, Moura I (1998) ATP sulfurylases from sulfate-reducing bacteria of the genus Desulfovibrio. A novel metalloprotein containing cobalt and zinc. Biochemistry 37:16225-16232

Geipel G, Drewitz S, Viehweger K (2010) Detection of uranium(IV) by LIPAS in biologic relevant samples. In: Annual Report 2010, Institute of Radiochemistry. Helmholtz-Zentrum Dresden-Rossendorf e.V, Dresden, p 13

Gravot A, Lieutaud A, Verret F, Auroy P, Vavasseur A, Richaud P (2004) AtHMA3, a plant P-1B-ATPase, functions as a $\mathrm{Cd} / \mathrm{Pb}$ transporter in yeast. FEBS Lett $561: 22-28$

Grene R (2002) Oxidative Stress and Acclimation Mechanisms in Plants. In: The Arabidopsis Book 1., p e0036, doi:10.1199/tab.0036.1

Grill E, Winnacker EL, Zenk MH (1985) Phytochelatins: The Principal Heavy-Metal Complexing Peptides of Higher Plants. Science 230:674-676

Grill E, Winnacker EL, Zenk MH (1987) Phytochelatines, a class of heavy-metalbinding peptides from plants, are functionally analogous to metallothioneins. Proc Natl Acad Sci U S A 84:439-443

Guerinot ML (2000) The ZIP family of metal transporters. Biochim Biophys Acta (BBA) - Biomembranes 1465:190-198

Gupta R, Luan S (2003) Redox control of protein tyrosine phosphatases and mitogen-activated protein kinases in plants. Plant Physiol 132:1149-1152

Gustin JL, Loureiro ME, Kim D, Na G, Tikhonova M, Salt DE (2009) MTP1dependent $\mathrm{Zn}$ sequestration into shoot vacuoles suggests dual roles in Zn tolerance and accumulation in Zn-hyperaccumulating plants. Plant J 57:1116-1127

Habermann E, Crowell K, Janicki P (1983) Lead and other metals can substitute for $\mathrm{Ca}^{2+}$ in calmoduline. Arch Toxicol 54:61-70

Hall JL (2002) Cellular mechanisms for heavy metal detoxification and tolerance. J Exp Bot 53:1-11

Hall JL, Williams LE (2003) Transition metal transporters in plants. J Exp Bot 54:2601-2613

Hanikenne M, Talke IN, Haydon MJ, Lanz C, Nolte A, Motte P, Kroymann J, Weigel D, Kramer U (2008) Evolution of metal hyperaccumulation required cis-regulatory changes and triplication of HMA4. Nature 453:391-U344

Harris ED (1994) Iron-copper interactions - some new revelations. Nutr Rev 52:311-315

Haydon MJ, Cobbett CS (2007) Transporters of ligands for essential metal ions in plants. New Phytol 174:499-506

Hernandez LE, Cooke DT (1997) Modification of the root plasma membrane lipid composition of cadmium-treated Pisum sativum. J Exp Bot 48:1375-1381

Hernandez LE, Lozano-Rodriguez E, Garate A, Carpena-Ruiz R (1998) Influence of cadmium on the uptake, tissue accumulation and subcellular distribution of manganese in pea seedlings. Plant Sci 13:139-151

Hindt MN, Guerinot ML (2012) Getting a sense for signals: regulation of the plant iron deficiency response. Biochim Biophys Acta, Mol Cell Res 1823:1521-1530

House WA (1999) Trace element bioavailability as exemplified by iron and zinc. Field Crop Res 60:115-141

Howe GA, Schilmiller AL (2002) Oxylipin metabolism in response to stress. Curr Opin Plant Biol 5:230-236

Irving H, Williams RJP (1953) The stability of transition-metal complexes. J Chem Soc:3192-3210

Jakoby M, Wang HY, Reidt W, Weisshaar B, Bauer P (2004) FRU (BHLH029) is required for induction of iron mobilization genes in Arabidopsis thaliana. FEBS Lett 577:528-534
Johnston HB, Thomas SM, Atterwill CK (1993) Aluminium and iron-induced metabolic changes in neuroblastoma cell-lines and rat primary neural cultures. Toxicol Vitro 7:229-233

Keilig K, Ludwig-Müller J (2009) Effect of flavonoids on heavy metal tolerance in Arabidopsis thaliana seedlings. Bot Studies 50:311-318

Kidd PS, Llugany M, Poschenrieder C, Gunse B, Barcelo J (2001) The role of root exudates in aluminium resistance and silicon-induced amelioration of aluminium toxicity in three varieties of maize (Zea mays L.). J Exp Bot 52:1339-1352

Knight H (2000) Calcium Signaling During Abiotic Stress in Plants. International Review of Cytology - a Survey of Cell Biology, Vol 195. Academic Press Inc, San Diego, p 269

Kochian LV (1995) Cellular mechanisms of aluminium toxicity and resistance in plants. Annu Rev Plant Physiol Plant Mol Biol 46:237-260

Korshunova YO, Eide D, Clark WG, Guerinot ML, Pakrasi HB (1999) The IRT protein from Arabidopsis thaliana is a metal transporter with a broad substrate range. Plant Mol Biol 40:37-44

Krämer U (2010) Metal hyperaccumulation in plants. Ann Rev Plant Biol 61:517, Palo Alto

Krämer U, CotterHowells JD, Charnock JM, Baker AJM, Smith JAC (1996) Free histidine as a metal chelator in plants that accumulate nickel. Nature 379:635-638

Krämer U, Pickering IJ, Prince RC, Raskin I, Salt DE (2000) Subcellular localization and speciation of nickel in hyperaccumulator and non-accumulator Thlaspi species. Plant Physiol 122:1343-1354

Krämer U, Talke IN, Hanikenne M (2007) Transition metal transport. FEBS Lett 581:2263-2272

Krupa Z, Siedlecka A, Skorzynska-Polit E, Maksymiek W, Prasad MNV, Strzalka K (2002) Heavy Metal Interactions with Plant Nutrients. In: Physiology and Biochemistry of Metal Toxicity and Tolerance in Plants. Kluwer Academic Publishers, Dordrecht, Boston, London, p 287

Küpper H, Küpper F, Spiller M (1996) Environmental relevance of heavy metalsubstituted chlorophylls using the example of water plants. J Exp Bot 47:259-266

Küpper H, Lombi E, Zhao FJ, McGrath SP (2000) Cellular compartmentation of cadmium and zinc in relation to other elements in the hyperaccumulator Arabidopsis halleri. Planta 212:75-84

Küpper H, Parameswaran A, Leitenmaier B, Trtilek M, Setlik I (2007) Cadmiuminduced inhibition of photosynthesis and long-term acclimation to cadmium stress in the hyperaccumulator Thlaspi caerulescens. New Phytol 175:655-674

Leszczyszyn OI, Schmid R, Blindauer CA (2007) Toward a property/function relationship for metallothioneins: Histidine coordination and unusual cluster composition in a zinc-metal lothionein from plants. Prot-Struct Funct Bioinform 68:922-935

Lin YF, Aarts MGM (2012) The molecular mechanism of zinc and cadmium stress response in plants. Cell Mol Life Sci 69:3187-3206

Ling HQ, Bauer P, Bereczky Z, Keller B, Ganal M (2002) The tomato fer gene encoding a bHLH protein controls iron-uptake responses in roots. Proc Natl Acad Sci U S A 99:13938-13943

Liu XM, Kim KE, Kim KC, Nguyen XC, Han HJ, Jung MS, Kim HS, Kim SH, Park HC, Yun DJ, Chung WS (2010) Cadmium activates Arabidopsis MPK3 and MPK6 via accumulation of reactive oxygen species. Phytochem 71:614-618

Long TA, Tsukagoshi H, Busch W, Lahner B, Salt DE, Benfey PN (2010) The bHLH transcription factor POPEYE regulates response to iron deficiency in Arabidopsis roots. Plant Cell 22:2219-2236

Ma JF, Ueno D, Zhao FJ, McGrath SP (2005) Subcellular localisation of Cd and Zn in the leaves of a Cd-hyperaccumulating ecotype of Thlaspi caerulescens. Planta 220:731-736

Maksymiec W (2011) Effects of jasmonate and some other signalling factors on bean and onion growth during the initial phase of cadmium action. Biol Plant 55:112-118

Maret W (2012) New perspectives of zinc coordination environments in proteins. J Inorgan Biochem 111:110-116

Marschner H, Römheld V (1983) In-vivo measurement of root-induced pH changes at the soil-root interface - effect of plant-species and nitrogen-source. Zeits Pflanzenphysiol 111:241-251

McCabe MJ, Nicotera P, Orrenius S (1992) Calcium dependent cell-death - role of the endonuclease, protein kinase $\mathrm{C}$, and chromatin conformation. Ann NY Acad Sci 663:269-278

Mendoza- Cózatl DG, Zhai Z, Jobe TO, Akmakjian GZ, Song WY, Limbo O, Russell MR, Kozlovskyy VI, Martinoia E, Vatamaniuk OK, Russell P, Schroeder JI (2010) 
Tonoplast-localized Abc2 transporter mediates phytochelatin accumulation in vacuoles and confers cadmium tolerance. J Biol Chem 285:40416-40426

Mihalik J, Henner P, Frelon S, Camilleri V, Fevrier L (2012) Citrate assisted phytoextraction of uranium by sunflowers: Study of fluxes in soils and plants and resulting intra-planta distribution of Fe and U. Environ Exp Bot 77:249-258

Misson J, Henner P, Morello M, Floriani M, Wu TD, Guerquin-Kern JL, Fevrier L (2009) Use of phosphate to avoid uranium toxicity in Arabidopsis thaliana leads to alterations of morphological and physiological responses regulated by phosphate availability. Environ Exp Bot 67:353-362

Monnet F, Vaillant N, Vernay P, Coudret A, Sallanon H, Hitmi A (2001) Relationship between PSII activity, $\mathrm{CO}_{2}$ fixation, and $\mathrm{Zn} \mathrm{Mn}$ and $\mathrm{Mg}$ contents of Lolium perenne under zinc stress. J Plant Physiol 158:1137-1144

Mortvedt JJ (1994) Plant and soil relationships of uranium and thorium decay series radionuclides - a review. J Environ Qual 23:643-650

Moulis JM (2010) Cellular mechanisms of cadmium toxicity related to the homeostasis of essential metals. Biometals 23:877-896

Murthy TCS, Weinberger P, Measures MP (1984) Uranium effects on the the growth of soybean (Glycine max L MERR). Bull Environ Contam Toxicol 32:580-586

Mysliwa-Kurdziel B, Prasad MNV, Strzalka K (2004) Heavy Metal Stress in Plants. Springer, Berlin, Heidelberg, p 127

Nielsen HD, Brown MT, Brownlee C (2003) Cellular responses of developing Fucus serratus embryos exposed to elevated concentrations of $\mathrm{Cu}^{2+}$. Plant Cell Environ 26:1737-1747

Noctor G (2006) Metabolic signalling in defence and stress: the central roles of soluble redox couples. Plant Cell Environ 29:409-425

Noctor G, Queval G, Mhamdi A, Chaouch S, Foyer CH (2011) Glutathione. In: The Arabidopsis Book, vol 9., p e0142, doi:10.1199/tab.0142

Ogawa I, Nakanishi H, Mori S, Nishizawa NK (2009) Time course analysis of gene regulation under cadmium stress in rice. Plant Soil 325:97-108

Ouzounidou G (1995) Cu-ions mediated changes in growth, chlorophyll and other ion contents in a Cu-tolerant Koeleria splendens. Biol Plant 37:71-78

Papoyan A, Kochian LV (2004) Identification of Thlaspi caerulescens genes that may be involved in heavy metal hyperaccumulation and tolerance. Characterization of a novel heavy metal transporting ATPase. Plant Physiol 136:3814-3823

Pekal A, Biesaga M, Pyrzynska K (2011) Interaction of quercetin with copper ions: complexation, oxidation and reactivity towards radicals. Biometals 24:41-49

Pence NS, Larsen PB, Ebbs SD, Letham DLD, Lasat MM, Garvin DF, Eide D, Kochian LV (2000) The molecular physiology of heavy metal transport in the Zn/Cd hyperaccumulator Thlaspi caerulescens. Proc Natl Acad Sci U S A 97:4956-4960

Prasad MNV (1995) Inhibition of maize leaf chlorophylls, carotenoids and gasexchange functions by cadmium. Photosynthetica 31:635-640

Puig S, Penarrubia L (2009) Placing metal micronutrients in context: transport and distribution in plants. Curr Opin Plant Biol 12:299-306

Punshon T, Guerinot ML, Lanzirotti A (2009) Using synchrotron X-ray fluorescence microprobes in the study of metal homeostasis in plants. Ann Bot 103:665-672

Rauser WE (1999) Structure and function of metal chelators produced by plants the case for organic acids, amino acids, phytin, and metallothioneins. Cell Biochem Biophys 31:19-48

Rentel MC, Lecourieux D, Ouaked F, Usher SL, Petersen L, Okamoto H, Knight H, Peck SC, Grierson CS, Hirt H, Knight MR (2004) OXI1 kinase is necessary for oxidative burst-mediated signalling in Arabidopsis. Nature 427:858-861

Richardt G, Federolf G, Habermann E (1986) Affinity of heavy metal ions to intracellular $\mathrm{Ca}^{2+}$-binding proteins. Biochem Pharmacol 35:1331-1335

Robinson NJ, Winge DR (2010) Copper Metallochaperones. Ann Rev Biochem Ann Rev 79:537-562

Römheld V, Marschner H (1986) Evidence for a specific uptake system for iron phytosiderophores in roots of grasses. Plant Physiol 80:175-180

Roos W, Evers S, Hieke M, Tschöpe M, Schumann B (1998) Shifts of intracellular $\mathrm{pH}$ distribution as a part of the signal mechanism leading to the elicitation of benzophenanthridine alkaloids - Phytoalexin biosynthesis in cultured cells of Eschscholtzia californica. Plant Physiol 118:349-364

Salt DE, Prince RC, Baker AJM, Raskin I, Pickering IJ (1999) Zinc ligands in the metal hyperaccumulator Thlaspi caerulescens as determined using X-ray absorption spectroscopy. Environ Sci Technol 33:713-717

Sanders D, Brownlee C, Harper JF (1999) Communicating with Calcium. Plant Cell 11:691-706

Santi S, Schmidt W (2009) Dissecting iron deficiency-induced proton extrusion in Arabidopsis roots. New Phytol 183:1072-1084
Schafer FQ, Buettner GR (2001) Redox environment of the cell as viewed through the redox state of the glutathione disulfide/glutathione couple. Free Radic Biol Med 30:1191-1212

Schat H, Llugany M, Vooijs R, Hartley-Whitaker J, Bleeker PM (2002) The role of phytochelatins in constitutive and adaptive heavy metal tolerances in hyperaccumulator and non-hyperaccumulator metallophytes. J Exp Bot 53:2381-2392

Schneider T, Schellenberg M, Meyer S, Keller F, Gehrig P, Riedel K, Lee Y, Eberl L, Martinoia E (2009) Quantitative detection of changes in the leaf-mesophyll tonoplast proteome in dependency of a cadmium exposure of barley (Hordeum vulgare L.) plants. Proteomics 9:2668-2677

Sharma SS, Dietz KJ (2006) The significance of amino acids and amino acidderived molecules in plant responses and adaptation to heavy metal stress. J Exp Bot 57:711-726

Sharma SS, Dietz KJ (2009) The relationship between metal toxicity and cellular redox imbalance. Trends Plant Sci 14:43-50

Siedlecka A, Tukendorf A, Skorzynska-Polit E, Maksymiec W, Wojcik M, Baszynski T, Krupa Z, Prasad MNV (2001) Selected Angiosperms Families Response to Heavy Metals in the Environment. In: Metals in the Environment: Analysis by Biodiversity. Marcel Dekker Inc, New York, p 171

Song WY, Park J, Mendoza-Cozatl DG, Suter-Grotemeyer M, Shim D, Hortensteiner S, Geisler M, Weder B, Rea PA, Rentsch D, Schroeder JI, Lee Y, E. Martinoia E (2010) Arsenic tolerance in Arabidopsis is mediated by two ABC-type phytochelatin transporters. Proc Natl Acad Sci U S A 107:21187-21192

Stefanov K, Seizova K, Popova I, Petkov V, Kimenov G, Popov S (1995) Effect of lead ions on the phospholipid composition in leaves of Zea mays and Phaseolus vulgaris. J Plant Physiol 147:243-246

Stohs SJ, Bagchi D (1995) Oxidative mechanisms in the toxicity of metal-ions. Free Radic Biol Med 18:321-336

Straczek A, Wannijn J, Van Hees M, Thijs H, Thiry Y (2009) Tolerance of hairy roots of carrots to $U$ chronic exposure in a standardized in vitro device. Environ Exp Bot 65:82-89

Sun Q, Ye ZH, Wang XR, Wong MH (2007) Cadmium hyperaccumulation leads to an increase of glutathione rather than phytochelatins in the cadmium hyperaccumulator Sedum alfredii. J Plant Physiol 164:1489-1498

Susin S, Abian J, Sanchez-Baeza F, Peleato ML, Abadia A, Gelpi E, Abadia J (1993) Riboflavin 3'- and 5'-sulfate, two novel flavins accumulating in the roots of iron-deficient sugar beet (Beta vulgaris). J Biol Chem 268:20958-20965

Symeonidis L, Karataglis S (1992) Interactive effects of cadmium, lead and zinc on root-growth of 2 metal tolerant genotypes of Holcus lanatus L. Biometals 5:173-178

Tottey S, Waldron KJ, Firbank SJ, Reale B, Bessant C, Sato K, Cheek TR, Gray J, Banfield MJ, Dennison C, Robinson NJ (2008) Protein-folding location can regulate manganese-binding versus copper- or zinc-binding. Nature 455:1138-1142

Turner JG, Ellis C, Devoto A (2002) The jasmonate signal pathway. Plant Cell 14:S153-S164

Uraguchi S, Watanabe I, Yoshitomi A, Kiyono M, Kuno K (2006) Characteristics of cadmium accumulation and tolerance in novel Cd-accumulating crops, Avena strigosa and Crotalaria juncea. J Exp Bot 57:2955-2965

Vacchina V, Mari S, Czernic P, Marques L, Pianelli K, Schaumloffel D, Lebrun M, Lobinski $R$ (2003) Speciation of nickel in a hyperaccumulating plant by high-performance liquid chromatography-inductively coupled plasma mass spectrometry and electrospray MS/MS assisted by cloning using yeast complementation. Anal Chem 75:2740-2745

Van Assche F, Clijsters H (1986) Inhibition of photosynthesis in Phaseolus vulgaris by treatment with toxic concentration of zinc - effect on ribulose-1,5-bisphosphate carboxylase oxygenase. J Plant Physiol 125:355-360

Van Assche F, Clijsters H (1990) Effects of metals on enzyme-activity in plants. Plant Cell Environ 13:195-206

van de Mortel JE, Villanueva LA, Schat H, Kwekkeboom J, Coughlan S, Moerland PD, van Themaat EVL, Koornneef M, Aarts MGM (2006) Large expression differences in genes for iron and zinc homeostasis, stress response, and lignin biosynthesis distinguish roots of Arabidopsis thaliana and the related metal hyperaccumulator Thlaspi caerulescens. Plant Physiol 142(3):1127-1147

Vandenhove H, Cuypers A, Van Hees M, Koppen G, Wannijn J (2006) Oxidative stress reactions induced in beans (Phaseolus vulgaris) following exposure to uranium. Plant Physiol Biochem 44:795-805

Vatamaniuk OK, Mari S, Lu YP, Rea PA (2000) Mechanism of heavy metal ion activation of phytochelatin (PC) synthase - Blocked thiols are sufficient for PC synthase-catalyzed transpeptidation of glutathione and related thiol peptides. J Biol Chem 275:31451-31459 
Vazquez MD, Poschenrieder C, Barcelo J (1992) Ultrastructural effects and localisation of low cadmium concentrations in bean roots. New Phytol 120:215-226

Viehweger K, Geipel G (2010) Uranium accumulation and tolerance in Arabidopsis halleri under native versus hydroponic conditions. Environ Exp Bot 69:39-46

Viehweger K, Schwartze W, Schumann B, Lein W, Roos W (2006) The G alpha protein controls a pH-dependent signal path to the induction of phytoalexin biosynthesis in Eschscholzia californica. Plant Cell 18:1510-1523

Viehweger K, Geipel G, Bernhard G (2011) Impact of uranium (U) on the cellular glutathione pool and resultant consequences for the redox status of $U$. Biometals 24:1197-1204

Vorwieger A, Gryczka C, Czihal A, Douchkov D, Tiedemann J, Mock HP, Jakoby M, Weisshaar B, Saalbach I, Baumlein H (2007) Iron assimilation and transcription factor controlled synthesis of riboflavin in plants. Planta 226:147-158

Wang W (1991) Literature review on higher plants for toxicity testing. Water, Air Soil Poll 59:381-400

Weber M, Trampczynska A, Clemens S (2006) Comparative transcriptome analysis of toxic metal responses in Arabidopsis thaliana and the $\mathrm{Cd}^{2+}$-hypertolerant facultative metallophyte Arabidopsis halleri. Plant Cell Environ 29:950-963

Weisskopf L, Tomasi N, Santelia D, Martinoia E, Langlade NB, Tabacchi R, AbouMansour E (2006) Isoflavonoid exudation from white lupin roots is influenced by phosphate supply, root type and cluster-root stage. New Phytol 171:657-668

Wildner GF, Henkel J (1979) Deactivation and reactivation of ribulose-1,5-bisphosphate carboxylase and oxygenase during air-argon-oxygen transitions. FEBS Lett 103:246-249

Wojas S, Ruszczyńska A, Bulska E, Clemens S, Antosiewicz DM (2010) The role of subcellular distribution of cadmium and phytochelatins in the generation of distinct phenotypes of AtPCS1- and CePCS3-expressing tobacco. J Plant Physiol 167:981-988

Xiong L, Zhu JK (2002) Molecular and genetic aspects of plant responses to osmotic stress. Plant Cell Environ 25:131-139

Yeh CM, Chien PS, Huang HJ (2007) Distinct signalling pathways for induction of MAP kinase activities by cadmium and copper in rice roots. J Exp Bot 58:659-671

Yuan YX, Zhang J, Wang DW, Ling HQ (2005) AtbHLH29 of Arabidopsis thaliana is a functional ortholog of tomato FER involved in controlling iron acquisition in strategy I plants. Cell Res 15:613-621

Yuan YX, Wu HL, Wang N, Li J, Zhao WN, Du J, Wang DW, Ling HQ (2008) FIT interacts with AtbHLH38 and AtbHLH39 in regulating iron uptake gene expression for iron homeostasis in Arabidopsis. Cell Research 18:385-397

Zengin FK (2006) The effects of $\mathrm{Co}^{2+}$ and $\mathrm{Zn}^{2+}$ on the contents of protein, abscisic acid, proline and chlorophyll in bean (Phaseolus vulgaris cv. Strike) seedlings. J Environ Biol 27:441-448

Zhang GP, Fukami M, Sekimoto H (2000) Genotypic differences in effects of cadmium on growth and nutrient compositions in wheat. J Plant Nutr 23:1337-1350

Zhu JK (2002) Salt and drought stress signal transduction in plants. Ann Rev Plant Biol 53:247-273

doi:10.1186/1999-3110-55-35

Cite this article as: Viehweger: How plants cope with heavy metals. Botanical Studies 2014 55:35.

\section{Submit your manuscript to a SpringerOpen ${ }^{\circ}$ journal and benefit from:}

- Convenient online submission

- Rigorous peer review

- Immediate publication on acceptance

- Open access: articles freely available online

- High visibility within the field

- Retaining the copyright to your article

Submit your next manuscript at $>$ springeropen.com 